A N N A LES

UNIVERSITATIS MARIAE CURIE-SKŁODOWSKA

L U B L I N - P O L O N I A

VOL. LXVII, 1

SECTIO B

2012

Maria Curie-Skłodowska University in Lublin, Faculty of Earth Sciences and Spatial Management

Department of Geology and Lithosphere Protection ${ }^{1}$, Laboratory of Geographical Information

Systems ${ }^{2}$

RENATA KOŁODYŃSKA-GAWRYSIAK ${ }^{1}$, ŁUKASZ CHABUDZIŃSKI ${ }^{2}$

\title{
Morphometric features and distribution of closed depressions on the Nałęczów Plateau (Lublin Upland, SE Poland)
}

Cechy morfometryczne oraz rozmieszczenie zagłębień bezodpływowych na Płaskowyżu Nałęczowskim (Wyżyna Lubelska, Polska południowo-wschodnia)

\begin{abstract}
The paper presents morphometric features and distribution of closed depressions in the loess areas of the Nałęczów Plateau, a geomorphological subregion in the north-western part of the Lublin Upland (SE Poland). The area is covered by loess, whose thickness ranges from several to $30 \mathrm{~m}$. The loess cover lies on thick series of lithologically and genetically diversified glacigenic sediments of the odra glaciation. An inventory of closed depressions was made based on 1: 10000 scale topographic maps; subsequently, quantitative analyses of the basic morphometric features of closed depressions, i.e. circumference, area, depth, maximum length and compactness (shape) of the depressions were performed using the ArcGIS 9x programme. Spatial analyses were performed in order to identify regularities in the distribution of the closed depressions on the Nałęczów Plateau; the analyses were based on the following quantitative features: density, concentration areas, distribution against landform and ranges of altitude (height a.s.l.).

The investigations demonstrated similarities between the depressions in terms of the area, maximum length, shape (compactness) and depth. Differences in the distribution of the closed depressions related to the different surface features in the eastern and western parts of the Nałęczów Plateau were documented. Extract areas with a high density of depressions were distinguished and referred to as closed depression regions (density exceeding 10 objects/ $\mathrm{km}^{2}$, maximum 40 objects/ $\mathrm{km}^{2}$ ); they exhibit individual features in terms of morphometry and distribution of the closed depressions.
\end{abstract}

Key words: closed depressions (wymoki), loess, Nałęczów Plateau, Lublin Upland 


\section{INTRODUCTION}

Closed depressions are micro- and meso-forms of surface features in loess areas. Compared to the zones of the loess landscape distinguished by Maruszczak (1961), closed depressions are major elements of the loess plateau. In the Polish literature, they are called "werteby" or "wymoki" (Maruszczak 1954, Czarnecki, Lewartowska-Urbańska 1987). The latter popular Polish term reflects the function in the landscape ascribed to these landforms, i.e. periodic accumulation of surface waters during spring snowmelt or prolonged precipitation, which often leads to "soaking" of crops. These landforms are characterized by a high diversity of water relations among which three types can be identified: closed depressions with a) stagnant water, b) periodic water, c) instantaneous water (Maruszczak 1954).

It is currently assumed that closed depressions in loess areas were formed in the post-glacial period through suffosive processes taking place in initial depressions in the loess cover (Maruszczak 1954). In Poland, closed depressions have been investigated on the Lublin Upland and Sandomierz Upland. The studies were focused on identification of the morphological features, distribution factors, genesis, and Holocene evolution of these landforms (Maruszczak 1954, Maruszczak, KoneckaBetley 1992, Czarnecki, Lewartowska-Urbańska 1987, Czarnecki, Solnceva 1992). Additionally, the role of suffosive processes in the evolution of depressions has been documented (Afelt $2007 \mathrm{a}, \mathrm{b}$ ). Closed depressions have also been investigated in central Belgium. The studies were focused on the morphological features, genesis, and evolution of the landforms, and particularly, on the human impact on the process (Gillijns et al. 2005, Vanwalleghem et al. 2007). In recent years, detailed investigations of the closed depressions on the Nałęczów Plateau were focused on the Holocene evolution of these landforms and they addressed the issue of their relevance for pre-historic settlement (Kołodyńska-Gawrysiak 2010).

\section{STUDY AREA}

The investigations were conducted in the area of the Nałęczów Plateau, a morphological sub-region in the north-western part of the Lublin Upland (Maruszczak 1972). The $493-\mathrm{km}^{2}$ region covers the area of ca. $45 \mathrm{~km}$ between the Vistula River valley in the west and the Bystrzyca River valley in the east. The northern border of the Plateau is a rectilinear edge running in the WNW-ESE direction. Its height reaches up to $30 \mathrm{~m}$. The southern border of the sub-region corresponds to the loess cover edge, and is clearly distinct in the western part of the area (Maruszczak 1972).

The loess cover of the Nałęczów Plateau is composed of a series of patches that are a peculiarity in the western part of the region. The different size loess patches are separated from each other by non-loess zones, which constitute longi- 
tudinal and latitudinal passages (currently coinciding with the direction of some valleys) dissecting the loess cover (Harasimiuk, Henkiel 1976). The loess thickness is also highly diverse. The loess cover is $20 \mathrm{~m}$ and locally $30 \mathrm{~m}$ thick in the western part of the region near the Vistula River valley. Maximum values of loess thickness have been reported from the northern edge of the Plateau, and along the latitudinal valley sections, where they may exceed $30 \mathrm{~m}$, likewise on the slopes of the Grodarz and Olszowiecka valleys. The loess thickness decreases towards the east. In the eastern part of the Nałęczów Plateau, the loess cover is 10-20 m thick, whereas on culminations it exceeds $20 \mathrm{~m}$ (Harasimiuk 1986). The loess cover lies on lithologically and genetically diversified glacigenic sediments originating from the odra glaciation. They are represented by a series of glacial tills of various thickness, water-glacial sands with gravel, and silts and stratified clay. By masking small forms of the loess substrate, the loess cover repeats its basic features, which are related to the diverse course of deglaciation processes during the recessive phases of the odra glaciation (Harasimiuk, Henkiel 1976). The maximum values of loess thickness are found in the zones of the highest denivelations of the loess substrate formed of thick series of glacial sediments (Harasimiuk, Henkiel 1976).

\section{METHODS}

The first stage of the research involved preparation of an inventory of closed depressions based on 1: 10000 topographic maps. Next, quantitative analyses of the basic morphometric features of the depressions, i.e. circumference perimeter, area, depth, maximum length, and compactness defining the shape of the depressions, were performed using the ArcGIS 9x programme. The maximum length of the catchment (L) was regarded as the maximum length of the depression (Lw) (Horton 1945, Schumm 1954). The compactness of the closed depression was calculated using the equation of the circulatory ratio $R k$ (Miller 1953, Gregory, Walling 1973):

$$
\text { (1) } R k=(4 p A) / P^{2}
$$

where $\mathrm{A}$ is the area of the closed depression, $\mathrm{P}$ - the circumference of the closed depression.

The second step of the study involved spatial analyses aimed at identification of regularities in the distribution of the closed depressions on the Nałęczów Plateau. To this end, the following quantitative characteristics (parameters) were analysed: density, distribution against the surface features and altitude ranges (height a.s.l.).

The density was calculated in $1 \mathrm{~km}^{2}$ basic hexagon plots. The regions were defined based on the density of the closed depressions. The values of the absolute altitudes at which the depressions occur were achieved using the $5 \mathrm{~m}$ cell DEM 
(Digital Elevation Model). The DEM was generated based on the Numerical Terrain Model (NTM) developed for the LPIS (Agricultural Field Identification System) and on information obtained from 1:10 000 topographic maps.

\section{MORPHOMETRIC FEATURES OF CLOSED DEPRESSIONS}

\section{Area}

On the Nałęczów Plateau, 1,761 closed depressions were inventoried. They are characterized by highly varied areas ranging between $56 \mathrm{~m}^{2}$ and $40,000 \mathrm{~m}^{2}$. Objects with an area below 1,500 $\mathrm{m}^{2}$ are predominant; 1,217 forms of this type, i.e. over $69 \%$ of the total number of closed depressions, were recorded in the entire region (Fig. 1). Nearly $3 / 4$ of them are objects whose area does not exceed $1,000 \mathrm{~m}^{2}$. The second largest group of the closed depressions is characterized by an area in the range of $1,500-2,500 \mathrm{~m}^{2}$; these landforms account for nearly $17 \%$ of all the depressions in the region (Fig.1). The other forms are classified into 4 area ranges and they constitute a few per cent. The areas of the largest forms are in the range of $20,000-40,700 \mathrm{~m}^{2}$. In the study regions, 6 such forms were recorded, one of them was the largest, i.e. $40,608.4 \mathrm{~m}^{2}$. Taking into account their area, 4 types of closed depressions were distinguished: small, medium-sized, large, and very large.

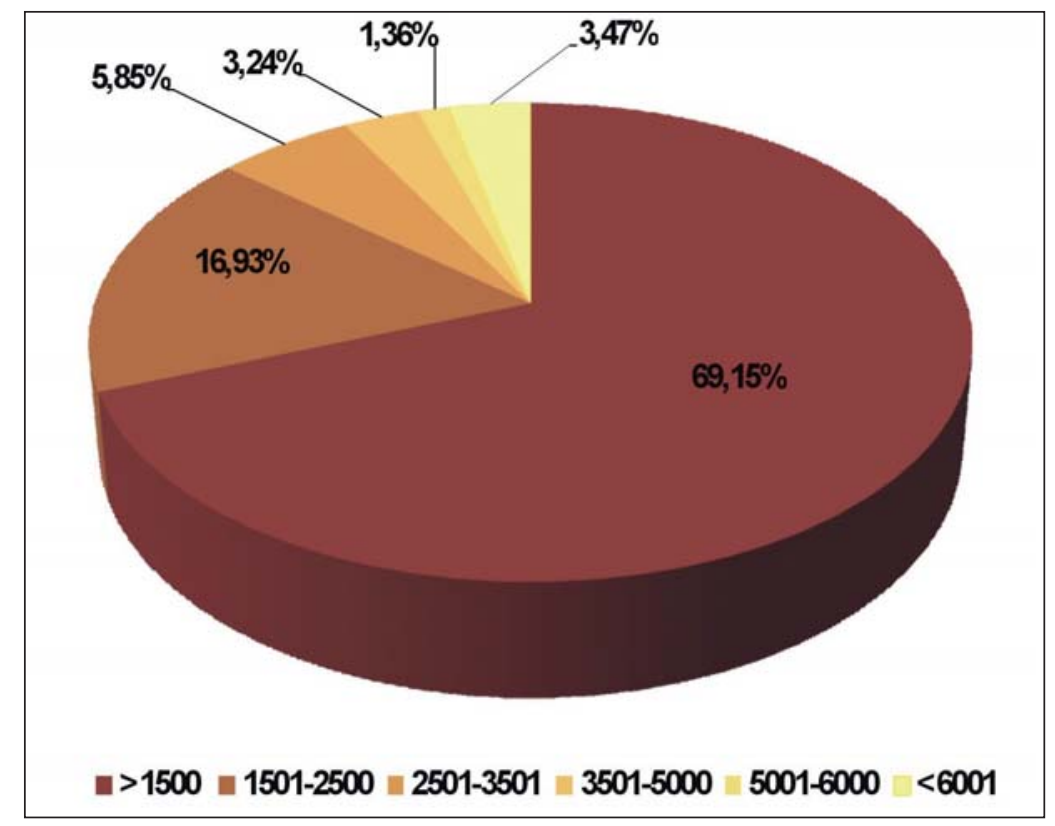

Fig. 1. The area of closed depressions on the Nałęczów Plateau $\left(\mathrm{m}^{2}\right)$ 


\section{Maximum length}

The values of this parameter of the objects studied range between 11 and $362 \mathrm{~m}$. Depressions with a maximum length up to $80 \mathrm{~m}$ are predominant on the Nałęczów Plateau (Fig. 2). These objects constitute $85.74 \%$ of all the depressions. Nearly $2 / 3$ of the objects from this group are forms with a narrow range of length, i.e. 25-50 m; which accounts for over half $(51.39 \%)$ of all the closed depressions in the region. One in every ten closed depressions on the Nałęczów Plateau has a maximum length of 80-120 m (Fig. 2). Objects with the value of this parameter exceeding $120 \mathrm{~m}$ constituted the least numerous (only a few per cent) group (Fig. 2).

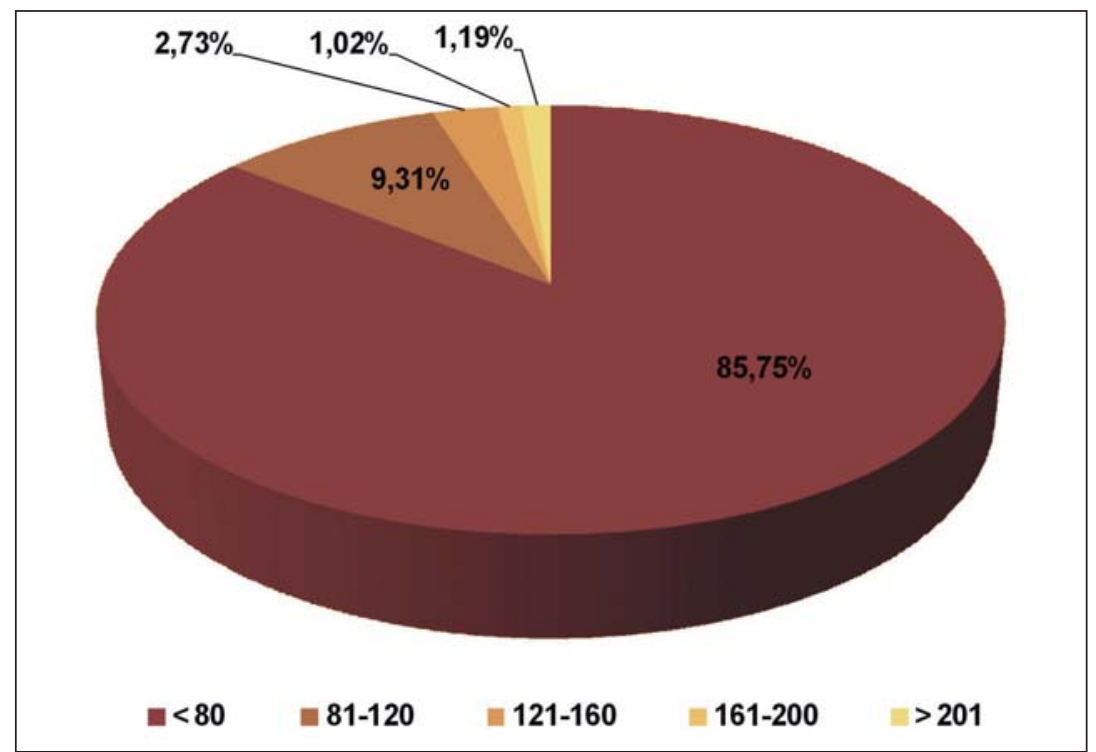

Fig. 2. Maximum length of closed depressions on the Nałęczów Plateau

\section{Depth}

Currently, a vast majority of the closed depressions are shallow forms, whose depth does not exceed $1.25 \mathrm{~m}$. They represent over $96 \%$ of all the study objects in the region. Closed depressions with a depth of $2.5 \mathrm{~m}$ are not numerous. On a regional scale, there are 62 forms of this type, which is slightly more than $3 \%$ of the objects studied. Only one object, located near Dębówka, is $3.75 \mathrm{~m}$ deep.

The depth of the closed depressions investigated currently is usually much lower than their original depth, due to deposition of deluvial sediments originating from soil denudation processes at a rate of 2-6 mm/year (Zgłobicki 2002). Some of the landforms have been filled up with deluvial sediments and are therefore not readable to modern geomorphology. 


\section{Compactness (shape)}

1. The compactness index for the depressions studied ranges from 188 to 185,162 . The high values of this parameter are characteristic of irregularly shaped objects. Forms that are more circular exhibit the lowest values of the compactness index.

Oval forms with the compactness index lower than 7,500 are predominant on the Plateau. On a regional scale, 1,447 objects of this type were recorded, which represents $82.16 \%$. The other $313(17.7 \%)$ of the closed depressions have an irregular shape. Larger forms dominate, which suggests that they may have originated through merging of neighbouring smaller objects. The closed depressions of the Nałęczów Plateau are characterized by gentle contours without clear edges between the slopes and bottoms of the particular forms.

\section{DISTRIBUTION OF CLOSED DEPRESSIONS}

On the Nałęczów Plateau, there is a distinct disproportion in the distribution of the closed depressions between the eastern and western parts of the region (Fig. 3). These differences are related to the specific surface features, which differ in the two parts. The biggest number of closed depressions is located in the eastern part of the Nałęczów Plateau. The area is to a lesser extent dissected by valley and gully systems than the western part. The mean gully density is $0.19 \mathrm{~km} / \mathrm{km}^{2}$, and the maximum density does not exceed $2 \mathrm{~km} / \mathrm{km}^{2}$ (Harasimiuk, Gawrysiak in this volume). The relative heights in the region reach $40-50 \mathrm{~m}$, and the slope aspect is $8-12^{\circ}$. Vast surfaces of an undulating loess plateau with numerous closed depressions are the predominant landscape elements (Fig. 3). Areas situated in the interfluve of the Ciemięga and Kurówka Rivers and Ciemięga and Minina Rivers (Fig. 4). The density of the landforms studied in this distinct, compact area exceeds 10 objects $/ \mathrm{km}^{2}$ and occasionally reaches 40 objects $/ \mathrm{km}^{2}$. The mean density of the closed depressions on the Nałęczów Plateau is 3-4 objects $/ \mathrm{km}^{2}$. A vast area with a high density of closed depressions stretches in the watershed zone of the Ciemięga and Czechówka Rivers, where the value of the density index reaches 30 objects $/ \mathrm{km}^{2}$ (Fig. 4). Moreover, a high density of closed depressions (over 10 objects $/ \mathrm{km}^{2}$ ) is a characteristic feature of a small area situated in the upper part of the Ciemięga River catchment, near Kolonia Tomaszowice and Kolonia Miłocin. The above-mentioned object exhibits the maximum values in the region, i.e. 40 objects $/ \mathrm{km}^{2}$. A large and quite compact area with a high density of closed depressions is situated near Sadurki, Marianka Ożarowska, and Miłocin. The density of the landforms studied reaches 20 objects $/ \mathrm{km}^{2}$. Small areas of concentration of the landforms investigated can be found near Stasin and Pliszczyn Kolonia, where the aforementioned index reaches 20 objects $/ \mathrm{km}^{2}$. 




Fig. 3. Distribution of closed depressions against the geomorphological map of the Nałęczów Plateau

In the western part of the Nałęczów Plateau, the closed depressions are less numerous (Fig. 3), particularly in its western margin adjacent to the Vistula River valley, where closed depressions can hardly be found. This area is strongly dissected by dry erosion-denudation valleys intersecting the bedrock and by gully systems, whose average density is $2.48 \mathrm{~km} / \mathrm{km}^{2}$, and the maximum density exceeds $10 \mathrm{~km} / \mathrm{km}^{2}$ (Harasimiuk, Gawrysiak in this volume). The development of gullies contributed to substantial dissection of the loess plateau tops (Fig. 3).They are preserved in the form of small fragments constituting fairly narrow inter-valley hummocks. The relative altitudes in the area exceed 40-50 m and reach $90 \mathrm{~m}$ in the neighbourhood of the Vistula River. The valley slopes are characterized by greater inclination reaching $15-20^{\circ}$ (Fig. 3). Areas with a high density of closed depressions are uncommon in the western part of the Plateau and are associated with occurrence of larger plateau patches. Only in a small area near Zażuk, Kolonia Klementowice, and Karmanowice does the density of these landforms reach 10 objects $/ \mathrm{km}^{2}$ (Fig. 4). In the neighbourhood of the Drzewce village, the density of the closed depressions is 20 objects $/ \mathrm{km}^{2}$, and in the nearby Kopanina village it reaches 30 objects/ $\mathrm{km}^{2}$ (Fig. 4).

\section{DISTRIBUTION OF CLOSED DEPRESSIONS AGAINST THE SURFACE FEATURES}

The analysis of the distribution of the closed depressions against the main surface features of the Nałęczów Plain has demonstrated that these landforms occur within 4 elements, i.e. loess plateau tops, valley slopes, denudation basins, 
and bottoms of erosion-denudation valleys. A majority of the closed depressions are concentrated on loess plateau tops. This location is characteristic of 1,269 , i.e. $72 \%$ of the objects studied (Fig. 5). Some closed depressions are located within denudation basins; this is the case of 285 objects constituting $16.18 \%$ of all the depressions in the region (Fig. 5). Closed depressions are rarely situated on slopes and bottoms of erosion-denudation valleys, as only a few per cent have been recorded in these landforms (Fig. 5).

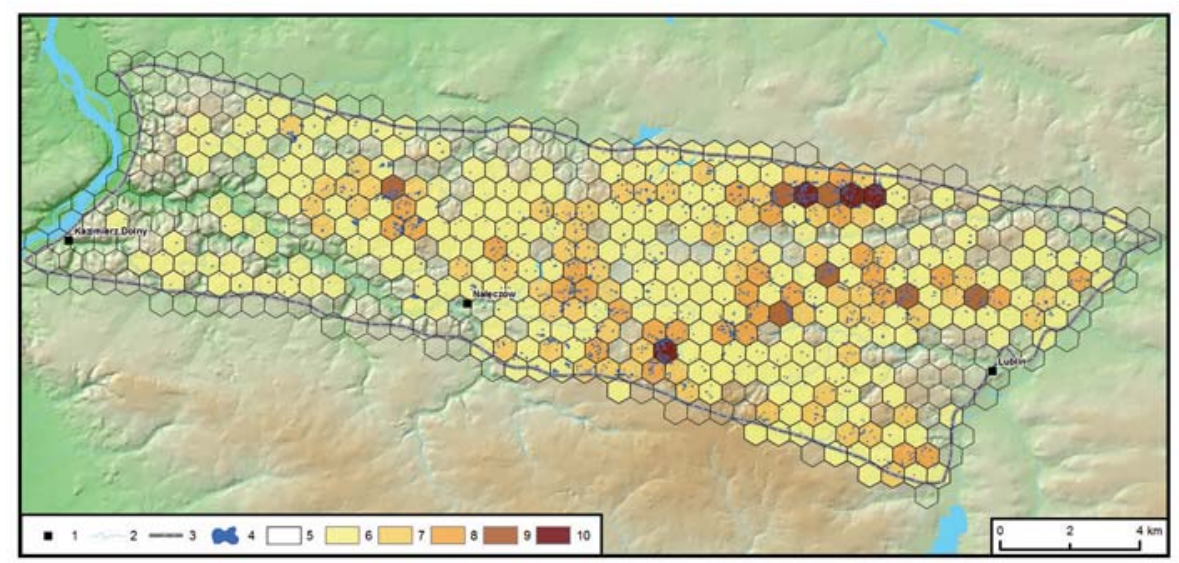

Fig. 4. Density of closed depressions on the Nałęczów Plateau (number $/ \mathrm{km}^{2}$ )

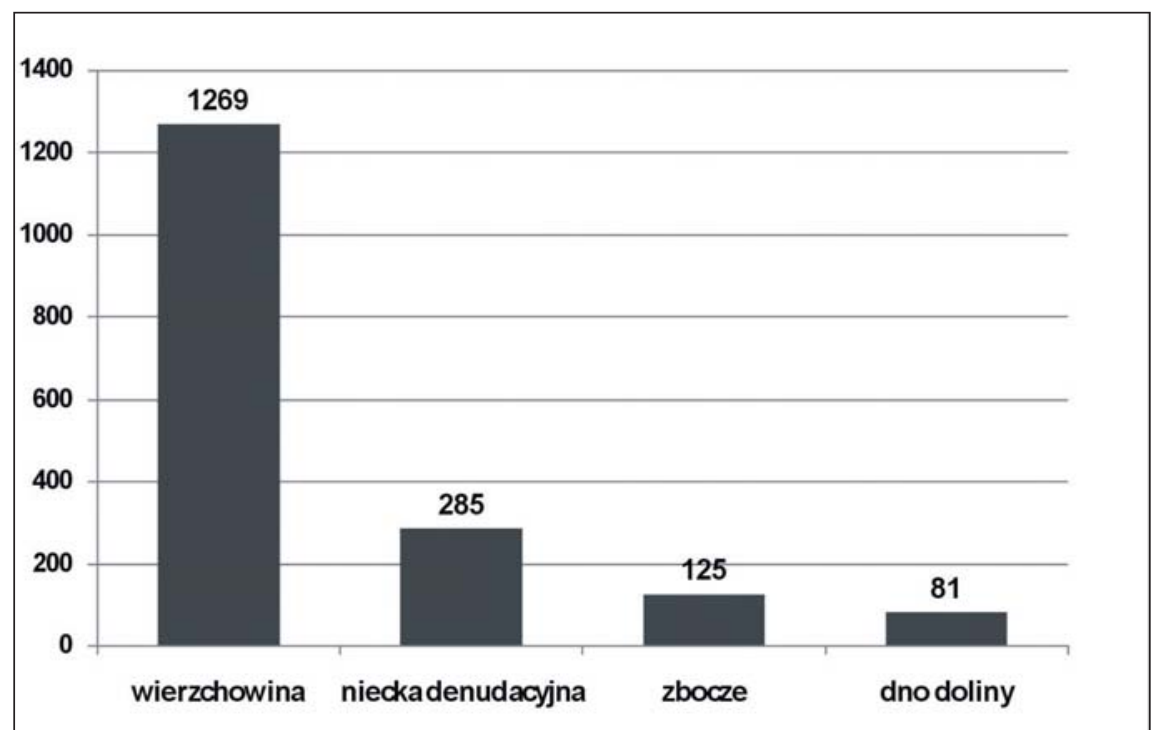

Fig. 5. Number of closed depressions against the main surface features of the loess areas on the Nałęczów Plateau. Explanation: wierzchowina - loess plateau top, niecka denudacyjna - denudation basin, zbocze - valley slope, dno doliny -bottom of erosion-denudation valley 
Table 2. Area of closed depressions in the respective regions of the Nałęczów Plateau

\begin{tabular}{|c|c|c|c|c|c|c|c|c|c|c|c|c|c|c|c|c|c|c|c|c|c|c|c|}
\hline \multirow{2}{*}{$\begin{array}{c}\text { Area } \\
{\left[\mathrm{km}^{2}\right]}\end{array}$} & \multirow{2}{*}{ Type } & \multicolumn{2}{|l|}{1} & \multicolumn{2}{|c|}{2} & \multicolumn{2}{|c|}{3} & \multicolumn{2}{|l|}{4} & \multicolumn{2}{|c|}{5} & \multicolumn{2}{|l|}{6} & \multicolumn{2}{|c|}{7} & \multicolumn{2}{|c|}{8} & \multicolumn{2}{|l|}{9} & \multicolumn{2}{|c|}{10} & \multicolumn{2}{|c|}{11} \\
\hline & & Number & $\%$ & Number & $\%$ & Number & $\%$ & Number & $\%$ & Number & $\%$ & Number & $\%$ & Number & $\%$ & Number & $\%$ & Number & $\%$ & Number & $\%$ & Number & $\%$ \\
\hline$<1500$ & Small & 11 & 44 & 22 & 62.86 & 52 & 59.77 & 34 & 68 & 35 & 50 & 129 & 56.30 & 84 & 68.85 & 226 & 70.84 & 312 & 74.46 & 111 & 82.83 & 41 & 73.21 \\
\hline $1501-2500$ & Medium & 6 & 24 & 5 & 14.28 & 16 & 18.39 & 15 & 24 & 17 & 24.2 & 50 & 21.83 & 20 & 16.39 & 56 & 17.55 & 60 & 14.31 & 15 & 11.19 & 9 & 16.07 \\
\hline $2501-3500$ & 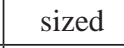 & 2 & 8 & 2 & 5.71 & 6 & 6.89 & 2 & 4 & 8 & 11.42 & 21 & 9.17 & 10 & 8.19 & 18 & 5.64 & 22 & 5.25 & 3 & 2.23 & 1 & 1.78 \\
\hline $3501-5000$ & Large & 1 & 4 & 2 & 5.71 & 4 & 4.59 & 1 & 2 & 5 & 7.14 & 7 & 3.05 & 2 & 1.36 & 10 & 3.13 & 12 & 2.83 & 5 & 3.73 & 3 & 5.35 \\
\hline $5001-6000$ & Large & 2 & 8 & 1 & 2.85 & 2 & 2.29 & - & & 1 & 1.42 & 8 & 3.49 & 2 & 1.63 & 3 & 0.94 & 2 & 0.47 & - & - & - & - \\
\hline$>6001$ & $\begin{array}{l}\text { Very } \\
\text { large }\end{array}$ & 3 & 12 & 3 & 8.57 & 6 & 6.89 & 2 & 4 & 4 & 5.71 & 14 & 6.1 & 4 & 3.27 & 6 & 1.88 & 11 & 2.62 & - & - & 2 & 3.57 \\
\hline Tot & & 25 & 100 & 35 & 100 & 87 & 100 & 50 & 100 & 70 & 100 & 229 & 100 & 122 & 100 & 319 & 100 & 419 & 100 & 134 & 100 & 56 & 100 \\
\hline
\end{tabular}

Table 3. Number of closed depressions against the major landforms of the closed depression regions of the Nałęczów Plateau

\begin{tabular}{|c|c|c|c|c|c|c|c|c|c|c|c|c|c|c|c|c|c|c|c|c|c|c|}
\hline $\begin{array}{c}\text { Major } \\
\text { landforms }\end{array}$ & Number & $\%$ & Number & $\%$ & Number & $\%$ & Number & $\%$ & Number & $\%$ & Number & $\%$ & Number & $\%$ & Number & $\%$ & Number & $\%$ & Number & $\%$ & Number & $\%$ \\
\hline $\begin{array}{c}\text { Loess } \\
\text { plateau tops }\end{array}$ & 16 & 64 & 25 & 71.40 & 71 & 81.6 & 41 & 82 & 44 & 62.8 & 143 & 62.44 & 74 & 60.65 & 253 & 79.31 & 328 & 78.28 & 96 & 71.64 & 52 & 92.85 \\
\hline $\begin{array}{c}\text { Denudation } \\
\text { basins }\end{array}$ & 3 & 12 & 3 & 8.57 & 11 & 12.64 & 4 & 8 & 19 & 27.14 & 56 & 24.45 & 32 & 26.22 & 40 & 12.53 & 61 & 14.55 & 9 & 6.71 & 3 & 5.35 \\
\hline $\begin{array}{l}\text { Valley } \\
\text { slopes }\end{array}$ & 1 & 4 & 1 & 2.85 & 3 & 3.44 & 2 & 4 & 3 & 4.28 & 10 & 4.36 & 13 & 10.65 & 18 & 5.64 & 21 & 5.01 & 26 & 19.40 & - & \\
\hline $\begin{array}{c}\text { Bottoms } \\
\text { of erosion- } \\
\text { denudation } \\
\text { valleys } \\
\end{array}$ & 5 & 20 & 6 & 17.10 & 2 & 2.29 & 3 & 6 & 5 & 7.14 & 20 & 8.73 & 3 & 2.45 & 8 & 2.50 & 10 & 2.38 & 3 & 2.23 & 1 & 1.78 \\
\hline Total & 25 & 100 & 35 & 100 & 87 & 100 & 50 & 100 & 70 & 100 & 229 & 100 & 122 & 100 & 319 & 100 & 419 & 100 & 134 & 100 & 56 & 100 \\
\hline
\end{tabular}


Areas located at the height between 210 to $230 \mathrm{~m}$ a.s.1. are rich in closed depressions and comprise ca. $67 \%$ of all the landforms in the region (Fig. 6). This altitude is the main level of the loess tops of the Nałęczów Plateau. In this region, areas lying within the altitude range of $220-225 \mathrm{~m}$ a.s.l. are particularly rich in closed depressions, as they contain nearly $1 / 4$ of all these landforms (Fig. 6). This altitude corresponds to that of loess plains, which are characterized by the highest density of closed depressions (the vicinity of Drzewce, Kopanina, Miłocin, Smugi, Piotrowice, and Płouszowice). The smallest number of closed depressions is found in areas situated at the lowest altitudes, i.e. within the height range of 170-200 m a.s.1. (Fig. 6).

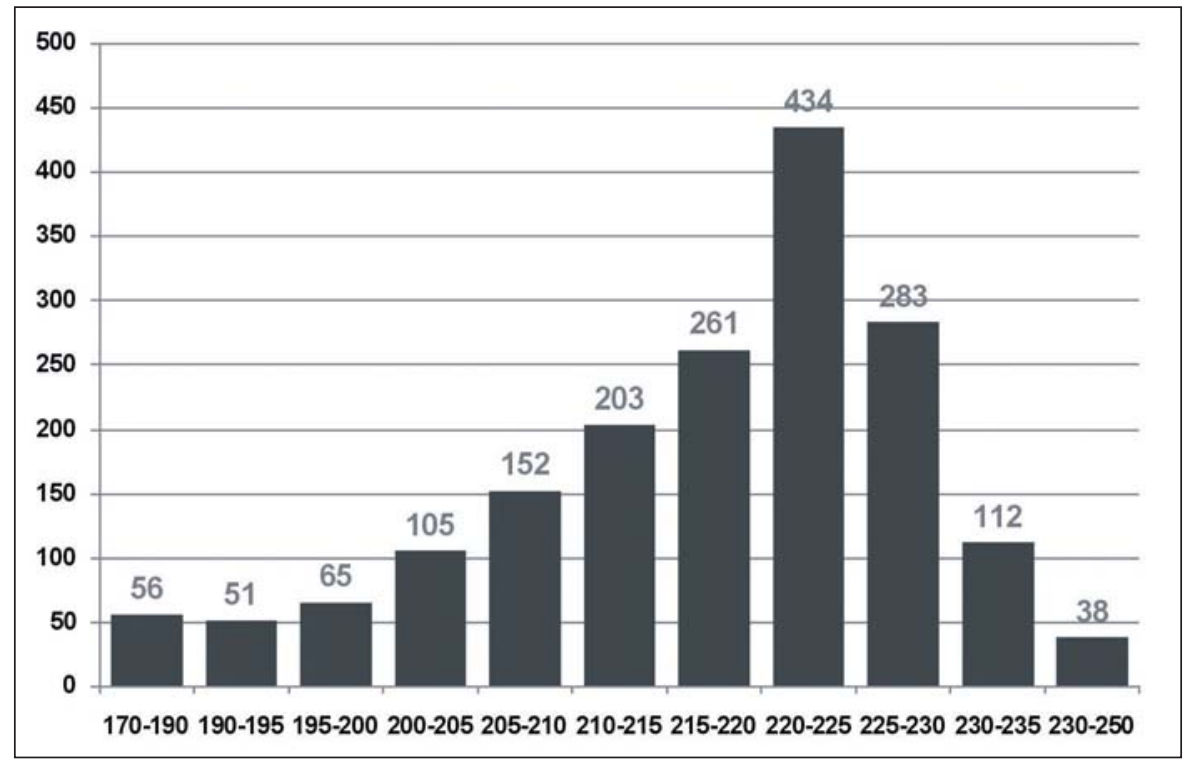

Fig. 6. Number of closed depressions in hypsometric layers of the Nałęczów Plateau

\section{REGIONS OF CLOSED DEPRESSION OCCURRENCE AND THEIR CHARACTERISTICS}

The analysis of the distribution of the closed depressions on the Nałęczów Plateau demonstrates presence of clearly privileged areas, which are quite compact, distinct and they are characterized by a high concentration of the depressions indicated by a high density index of these landforms. Eleven areas of this type referred to as the close depression regions have been distinguished in the entire region (Fig. 7). In the western part, 3 small regions located north of the Bystra River valley have been distinguished: the Klementowice-Zażuk region (1), the Karmanowice region (2), and the Kopanina-Drzewce region (3). The most numer- 
ous and largest closed depression regions are situated in the eastern part of the Plateau (Fig. 6). These include the Nałęczów-Czesławice region (4), the BogucinGutanów region (5), the Sadurki-Miłocin region (6), the Miłocin Kol.-Tomaszowice Kol. region (7), the Piotrawin-Smugi region (8), the Płouszowice-Rudnik region (9), the Konopnica-Stasin region (10), and the Pliszczyn Kol.-Marianówka region (11).



Fig. 7. Closed depression regions on the Nałęczów Plateau

\section{Klementowice-Zażuk}

The region is located in the western part of the Nałęczów Plateau. It is one of the smallest closed depression regions (an area of $4.72 \mathrm{~km}^{2}$ ) (Table 1). Compared with the other regions, it is characterized by the smallest number of closed depressions (25) and the lowest density value reaching over 5 objects $/ \mathrm{km}^{2}$. The closed depressions occurring in this region are highly varied in terms of their area. Small forms are predominant, although compared with other regions they constitute a relatively small proportion, i.e. $44 \%$ (Table 2). Six large closed depressions with an area exceeding $3,500 \mathrm{~m}^{2}$ constitute a substantial proportion, i.e. $24 \%$ of all the objects in this region. Half of them have an area of over $10,000 \mathrm{~m}^{2}$ (Table 2). One of the largest closed depressions of the Plateau with an area of $32,944 \mathrm{~m}^{2}$ belongs to this group. In this region, closed depressions are concentrated mainly in the area of a low plateau hummock located parallel to the northern margin of the Plateau at an altitude of 190-200 m a.s.l. In the southern part, the hummock is dissected by systems of erosion-denudation valleys entering the Bystra River valley and in the north, by valleys dissecting the zone of the northern edge of the Nałęczów Plateau (Fig.7). The investigated region is characterized by a large number $(20 \%)$ of closed depressions located on the bottoms of dry erosion-denudation valleys (Table 3 ). The third numerous group is constituted by landforms situated in denudation basins $(12 \%)$. 
Morphometric features and distribution of closed depressions on the Nałęczów...

Table 1. Selected characteristics of the closed depression regions of the Nałęczów Plateau

\begin{tabular}{|r|l|c|c|c|c|c|}
\hline \multirow{2}{*}{ No. } & \multicolumn{2}{|c|}{ Region } & & \multicolumn{3}{|c|}{ Characteristics of closed depression } \\
\cline { 4 - 7 } & & $\begin{array}{c}\text { Area } \\
{\left[\mathrm{km}^{2}\right]}\end{array}$ & $\begin{array}{c}\text { Number } \\
\text { of closed } \\
\text { depressions }\end{array}$ & $\begin{array}{c}\text { Mean } \\
\text { area } \\
{\left[\mathrm{m}^{2}\right]}\end{array}$ & $\begin{array}{c}\text { Mean } \\
\text { density } \\
\text { objects / } \\
\mathrm{km}^{2}\end{array}$ & $\begin{array}{c}\text { Mean } \\
\text { altitude } \\
{[\mathrm{m} \text { a.s.1.] }}\end{array}$ \\
\hline 1 & Klementowice-Zażuk & 4.72 & 25 & 3948.74 & 5.28 & 192.30 \\
\hline 2 & Karmanowice & 4.41 & 35 & 2207.68 & 7.93 & 201.28 \\
\hline 3 & Kopanina-Drzewce & 5.57 & 87 & 2654.26 & 15.61 & 215.82 \\
\hline 4 & Nałęczów-Czesławice & 7.94 & 50 & 2109.31 & 6.29 & 209.05 \\
\hline 5 & Bogucin-Gutanów & 9.73 & 70 & 2340.44 & 8.07 & 218.84 \\
\hline 6 & Sadurki-Miłocin & 28.36 & 229 & 2355.94 & 14.99 & 210.91 \\
\hline 7 & Miłocin Kol.-Tomaszowice Kol. & 8.13 & 122 & 1514.95 & 6.76 & 227.85 \\
\hline 8 & Piotrawin-Smugi & 20.58 & 319 & 1443.51 & 9.74 & 224.11 \\
\hline 9 & Płouszowice-Rudnik & 43.00 & 419 & 1352.72 & 15.49 & 219.38 \\
\hline 10 & Konopnica-Stasin & 19.79 & 134 & 919.417 & 6.66 & 222.82 \\
\hline 11 & Pliszczyn Kol.-Marianówka & 8.39 & 56 & 1613.92 & 7.18 & 196.45 \\
\hline
\end{tabular}

\section{Karmanowice}

This is the smallest of the defined regions $\left(4.41 \mathrm{~km}^{2}\right)$. It includes 35 closed depressions, whose mean density is almost 8 objects $/ \mathrm{km}^{2}$ (Table1). The main element of the surface features in this region is a low loess plateau top stretching at an altitude of 195-200 $\mathrm{m}$ a.s.l. In the east, the plateau top patch is delimited by the upper section of the Potok Klementowicki valley and in the west, by a large erosiondenudation valley. In the south-western part of the region the plateau reaches the height of 210-215 $\mathrm{m}$ a.s.l. The mean altitude of occurrence of closed depressions is $201.28 \mathrm{~m}$ a.s.1. They are mainly concentrated on the loess plateau top $(71.4 \%)$ and the bottoms of erosion-denudation valleys (17.1\%). A considerably smaller number of the landforms studied have been found within denudation basins $(8.57 \%)$, and the lowest number - on the slopes (2.85\%) (Table 3). Small landforms with areas below $1,500 \mathrm{~m}^{2}(62.85 \%)$ are predominant in the region. There are only 3 large closed depressions. Two of them have an area of ca. 7,000 $\mathrm{m}^{2}$, and one - over $14,000 \mathrm{~m}^{2}$.

\section{Kopanina-Drzewce}

This is one of the smallest closed depression regions with as many as 87 closed depressions concentrated in an area of $5.57 \mathrm{~km}^{2}$ (Table 1). Therefore, the region is characterized by the highest mean density of closed depressions on the Plateau and one of the highest maximum densities reaching 40 objects $/ \mathrm{km}^{2}$ (Fig. 4). The region is morphologically diverse. In its south-eastern part, the loess plateau reaches an altitude of 210-215 $\mathrm{m}$ a.s.l. The closed depressions are concentrated near the Stara Wieś-Drzewce Kolonia village. This aggregation is sur- 
rounded by distinct margins of loess cover accumulation. This specific "hollow" contains large-sized closed depressions (Fig. 7). In the north-western part of the region, there is a high plateau patch reaching a height of 220-229 $\mathrm{m}$ a.s.1. It forms a "loess cap" dissected by the upper sections of erosion-denudation valleys entering the Potok Olszowiecki valley in the east and the Potok Klementowicki valley in the west. The closed depressions in this part of the region are concentrated near the village of Kopanina (Fig. 7). Due to considerable 19-m denivelations, the mean altitude of occurrence of closed depressions is $215.82 \mathrm{~m}$ a.s.1. Over $81 \%$ of them are located on the plateau top (Table 2). Forms present in the denudation basins constitute a high proportion, i.e. $12.64 \%$. Single closed depressions are located on slopes and valley bottoms (Table 3). Small forms (up to 1,500 $\mathrm{m}^{2}$ ) that are predominant in the region constitute over half of all the forms found here (59.77\%). Concurrently, forms with an area exceeding 6,000 $\mathrm{m}^{2}$ (Table 2) represent a significant proportion. All the objects in this group are very large, as their areas exceed $10000 \mathrm{~m}^{2}$. The group comprises the largest closed depression (an area of $40,608 \mathrm{~m}^{2}$ ) on the Plateau.

\section{Nałęczów-Czesławice}

The region covers an area of $7.94 \mathrm{~km}^{2}$ (Table 1). There are 50 closed depressions here, whose mean density is over 6 objects $/ \mathrm{km}^{2}$. A majority of the depressions are small forms with an area below 1,500 $\mathrm{m}^{2}$ (Table 1). 24 such objects, which constitute $68 \%$ of all the depressions, have been inventoried. The area of nearly $1 / 4$ of these landforms does not exceed $2,500 \mathrm{~m}^{2}$. There are 2 large closed depressions with an area over $6,000 \mathrm{~m}^{2}$ (Table 2). The forms studied are concentrated mainly in the area of the loess plateau top. It rises at an altitude of 205-210 m a.s.1. near the Strzelce village and 210-220 m near Piotrowice and Czesławice. The closed depressions in this region are clearly concentrated on the plateau at the height of 215-220 m a.s.l. near Piotrowice Małe. The location on the plateau top is characteristic of $82 \%$ of all the inventoried landforms. The smallest numbers of closed depressions were found on the bottoms of denudation basins ( $8 \%$ ), valley bottoms (6\%), and slopes (2\%) (Table 3$)$.

\section{Bogucin-Gutanów}

The region is situated on a loess hummock stretching in the ENE-WSW direction, whose plateau top is located at a height of $220-225 \mathrm{~m}$ a.s.l. The hummock is dissected by valley systems entering the Kurówka River valley in the north (Fig. 7). The $9.73 \mathrm{~km}^{2}$ region comprises 70 closed depressions, whose mean density exceeds 8 objects $/ \mathrm{km}^{2}$ (Table 1). Half of the closed depressions are small-sized forms with an area below 1,500 $\mathrm{m}^{2}$ (Table 2). Medium-sized forms with an area below $3,500 \mathrm{~m}^{2}$ represent a substantial proportion here, i.e. they constitute $35 \%$ of all the closed depressions in the region (Table 2). There are 5 large and 4 very 
large depressions here, the biggest of which has an area of $24,900 \mathrm{~m}^{2}$. Most of the closed depressions, i.e. 44 forms constituting $62.8 \%$ (Table 3), are concentrated on the loess plateau. A characteristic feature is the high proportion of depressions located in denudation basins and bottoms of erosion-denudation valleys, which strongly dissect the plateau in the north. This has an impact on the mean altitude of occurrence of the closed depressions, which is lower than the altitude of the plateau top and reaches nearly $219 \mathrm{~m}$ a.s.l. Almost $33 \%$ of the depressions in this region are located in denudation basins, while ca. $7 \%$ are found on the bottoms of erosion-denudation valleys (Table 3). Single forms are situated on slopes (3 objects). The spatial distribution of the closed depressions clearly indicates concentrations of these landforms comprising several or a dozen or so forms. They are found near Garbów I and Gutanów and in the highest part of the region near Czesławice (Psie Górki, Żabie Duki).

\section{Sadurki-Miłocin}

The region is situated in the interfluve of the Ciemiegga and Bystra Rivers. With its area exceeding $28 \mathrm{~km}^{2}$, the region is one of the largest on the Nałęczów Plateau (Table 1). The region comprises 229 closed depressions and thus is the third biggest region of the Plateau in terms of abundance and mean density of these landforms. The distribution of the closed depressions is mainly related to the vast areas of the loess plateau, which rises at 220-225 m a.s.l. in the southeastern part of the region. Concentrations of closed depressions are located in the area of Miłocin, Kolonia Czajki, and Kolonia Maszki. Near Sadurki, the closed depressions are concentrated on lower plateau areas rising from 205 to $210 \mathrm{~m}$ a.s.l. In the northern part of the region near Kolonia Ożarów, the loess plateau top rises at an altitude of 215-220 m a.s.l. A characteristic feature of the region is variation of altitudes between the particular patches (levels) of the loess plateau tops. The closed depressions in this region occur at the average altitude of almost $211 \mathrm{~m}$ a.s.l. Most of them (62.44\%) are located on plateau tops (Table 3). Nearly $1 / 4$ of the closed depressions are situated in denudation basins. A considerable part of the depressions $(8.73 \%$ ) are located on the bottoms of erosion-denudation valleys (Table 3). Single forms are situated on slopes (4.36\%). Over half of the depressions in this region are the smallest forms with an area below 1,500 $\mathrm{m}^{2}$. On a regional scale, there is a considerable proportion of larger forms with areas exceeding $3,500 \mathrm{~m}^{2}$, which constitute over $18 \%$ of all the depressions. Fourteen, i.e. nearly half of them, are very large objects with an area exceeding $6,000 \mathrm{~m}^{2}$ (Table 2).

\section{Miłocin Kolonia-Tomaszowice Kolonia}

This is one of the smallest closed depression regions; however, it is clearly distinct due to its high compactness (Fig. 7).122 closed depressions are located in 
an area of $8.13 \mathrm{~km}^{2}$ (Table 1). Their mean density exceeds 6 objects $/ \mathrm{km}^{2}$, and the maximum density reaches 40 objects $/ \mathrm{km}^{2}$ (Table 1, Fig. 4). The main element of this region is a vast, undulating loess plateau exhibiting slight denivelations and rising from 230 to $232 \mathrm{~m}$ a.s.l. Its area comprises over $60 \%$ of closed depressions (Table 3). Numerous denudation basins, which ensure the characteristic undulation of the area, are a peculiarity of the region. This is reflected in the remarkable abundance of depressions located in such landforms. Every fourth closed depression in this region is situated in a denudation basin (Table 3 ). The greatest number of closed depressions, i.e. almost $70 \%$, is small forms with an area below $1,500 \mathrm{~m}^{2}$. There are only 4 largest forms with an area exceeding $6,000 \mathrm{~m}^{2}$ (Table 2).

\section{Piotrawin-Smugi}

The region is one of the largest on the Plateau. It covers an area of over $20 \mathrm{~km}^{2}$ and comprises 319 depressions, whose mean density exceeds 9 objects/ $\mathrm{km}^{2}$, and the maximum density reaches 40 objects $/ \mathrm{km}^{2}$ (Table 2, Fig. 4). The region is located within a latitudinal, asymmetrical loess plateau-ridge. A narrow plateau top rising to $225-230 \mathrm{~m}$ a.s.l. is a culmination in this area. It descends gently northwards to reach $220 \mathrm{~m}$ a.s.1., whereas in the south it descends along a steep slope towards the Ciemiega River valley. The slope is dissected by numerous short erosion-denudation valleys, whose upper sections reach the culmination of the plateau-ridge (Fig. 7). The northern gently inclined part of the plateau is more compact. It is only dissected by 3 long erosion-denudation valleys (Fig. 7). The closed depressions are concentrated in a narrow, latitudinal $1 \mathrm{~km}$-wide zone comprising the culmination parts of the loess plateau and its part that gently descends northwards (Fig. 7). Nearly $80 \%$ of the depressions in the region have such a position. Slightly over $12 \%$ of the landforms are located in denudation basins (Table 3). The mean altitude of the occurrence of the closed depressions is ca. $224 \mathrm{~m}$ a.s.1. In terms of the area, the region is predominated by small depressions below $1,500 \mathrm{~m}^{2}$; which constitute over $70 \%$ (Table 2 ). There are only 6 very large forms (almost 2\%); the largest of them has an area of 15,000 $\mathrm{m}^{2}$ (Table 2). In the culmination zones, small depressions are predominant. Larger forms are located in lower areas of the plateau (Fig. 7).

\section{Płouszowice-Rudnik}

The $43-\mathrm{km}^{2}$ area is the largest of all the closed depression regions (Table 1). It is characterized by the greatest number of depressions, i.e. 419 , whose mean density exceeds 15 objects $/ \mathrm{km}^{2}$ (Table 2). The region is situated on a wide intervalley hummock stretching between the Ciemiegga River valley in the north and the Czechówka River valley in the south (Fig. 7). In the central part of the hummock, there is a latitudinal zone of a distinct concentration of closed depressions, coinciding with the highest parts of the loess plateau top, which reaches $230 \mathrm{~m}$ 
a.s.l. near Panieńszczyzna and Płouszowice. The largest areas of the plateau tops in the region rise at an altitude of 220-225 m a.s.1.. In the eastern part near Rudnik, the plateau descends to an altitude of 200-215 m a.s.l. Over $78 \%$ of the depressions are located on plateau tops (Table 3). Depressions located in denudation basins exhibit a considerable proportion ( $14.5 \%$ of the forms). The mean altitude of occurrence of closed depressions is $219.38 \mathrm{~m}$ a.s.l. The region is dominated by small depressions with an area below $1,500 \mathrm{~m}^{2}$. They account for over $74 \%$ of the depressions (Table 2). The largest depressions represent an inconsiderable percentage of $2.62 \%$. Regularities in the distribution of the closed depressions in the study region can be observed; they are related to "passing round" the longitudinal erosion-denudation valleys dissecting the slopes of the Ciemięga and Czechówka valleys (Fig. 7). The closed depressions are concentrated on hummocks separating the neighbouring erosion-denudation valleys. This is well discernible in the zone of the left slope of the Czechówka River valley near Kolonia Dąbrowica, Kopanina near Płouszowice, and Wola Sławińska.

\section{Konopnica-Stasin}

In the west, the region comprises a high plateau hummock delimited by the Motycz valley in the north-west and by the Konopnica valley in the southeast. It covers an area of nearly $20 \mathrm{~km}^{2}$ (Table 1). 134 closed depressions with a density exceeding 6 objects $/ \mathrm{km}^{2}$ were inventoried in this region. The loess plateau near Motycz reaches a maximum altitude in the Nałęczów Plateau, i.e. 240-250 m a.s.l. It descends gently northwards towards the Czechówka River valley and reaches an altitude of 230-235 m a.s.l. near Pietrzakowizna, and 215-225 m a.s.1. near Szerokie. Distinct concentrations of closed depressions were found near the aforementioned villages. In the eastern part of the region near Konopnica, the plateau stretches horizontally at an altitude of 230-235 m a.s.1., and $220 \mathrm{~m}$ a.s.l. near Stasin. Concentrations of closed depressions are present in this area as well. More than $71 \%$ of the depressions are located on the plateau top (Table 3 ), whereas every fifth closed depression is situated on the slope. This location is characteristic of the highest percentage of the closed depressions among all the depression regions of the Nałęczów Plateau (Fig. 3). Nearly $83 \%$ of all these landforms present in this region are small landforms with an area below $1,500 \mathrm{~m}^{2}$. Absence of landforms larger than $5,000 \mathrm{~m}^{2}$ is a characteristic feature of this region (Fig. 2).

\section{Pliszczyn Kol.-Marianówka}

The region covers an area of $8.39 \mathrm{~km}^{2}$ (Table 1). It comprises a patch of a low loess plateau stretching near the Bystrzyca River valley at an altitude of 195-200 m a.s.1. (Fig. 7). Towards the north-west, the terrain rises reaching an altitude of 210-215 m a.s.l. in the area of Kol. Pliszczyn and Łagiewniki. On 
average, closed depressions occur here at an altitude of $196.45 \mathrm{~m}$ a.s.l. (Table 1). They are concentrated near Łysaków and Łagiewniki (Fig. 7). The mean density of these landforms is over 7 objects $/ \mathrm{km}^{2}$. Almost all the closed depressions in this region are located within the plateau top (92.83\%). Only 4 of the 56 objects have a different location (Table 3). Small closed depressions constituting over $73 \%$ of the objects are predominant (Table 2). The largest landforms are represented by 2 depressions, the biggest of which has an area exceeding $11,000 \mathrm{~m}^{2}$.

\section{REFERENCE}

Afelt A., 2007a: Wplyw rzeźby i zasilania na właściwości wód porowych w lessach, Annales UMCS vol. $62,223-242$.

Afelt A., 2007b: Suffozja: proces filtracyjnego przeksztatcania skaty, Prace i Studia WGSR, vol. 38, $157-172$.

Czarnecki R., Lewartowska-Urbańska M., 1987: Wymoki okolic Sandomierza, Przegląd Geograficzny, vol. LIX, f. 3, PWN, Warszawa, 385-397.

Czarnecki R., Solnceva N. P., 1992: Wymoki okolic Sandomierza (cz. II.), Przegląd Geograficzny, t. LXIII, f. 1-2, PWN, Warszawa, 143-149.

Gillijns K., Poesen J., Deckers J., 2005: On the characteristics and origin of closed depression in loess-derived soils in Europe - a case study from central Belgium, Catena 60, 43-58.

Gregory K. J., Walling D. E., 1973: Drainage Basin Form and Process. A Geomorphological Approach, Edward Arnold Ltd., London, 456.

Harasimiuk M., Henkiel A., 1976: Osobliwości pokrywy lessowej zachodniej części Płaskowyżu Natęczowskiego, Z badań czwartorzędu w Polsce, vol. 18, Wyd. Geol., Warszawa, 177-181.

Harasimiuk M., 1987: Lithologic properties as indices of the sedimentation conditions of the vistulian loesses in the eastern part of the Natęczów Plateau (SE Poland), Annales UMCS, sec. B, vol. XLI, 11, 179-202.

Harasimiuk M., Henkiel A., 1978: Wpływ budowy geologicznej i rzeźby podtoża na uksztaltowanie pokrywy lessowej w zachodniej części Płaskowyżu Nałęczowskiego, Annales UMCS, sec. B, vol. XXX/XXXI, 55-80.

Horton R. E., 1945: Erosional development of streams and their drainage basins; hydrophysical approach to quantitative morphology, Bulletin of the Geological Society of America, 56, $275-370$.

Kołodyńska-Gawrysiak R., Bienia M., 2010: Uwarunkowania i przebieg holoceńskiej denudacji w rejonie wielokulturowaj osady w Panieńszczyźnie koło Lublina, Prace i Studia Geograficzne, vol. 45, 89-104.

Maruszczak H., 1954: Werteby obszarów lessowych Wyżyny Lubelskiej, Annales UMCS, sec. B, vol. VIII, 123-237.

Maruszczak H., 1961: Le relief des terrains de loess le Plateau de Lublin, Annales UMCS, sec. B, vol. XV, 93-122.

Maruszczak H., 1972: Wyżyny Lubelsko-Wotyńskie, [in:] M. Klimaszewski (ed.), Geomorfologia Polski, vol. 1, Warszawa, 340-384.

Miller V. C., 1953: Quantitative geomorphological study of drainage basin characteristics in Clinch Mountain area, Tennessee. ONR Technical Report 3, Project No. 271-1030, New York, Columbia University.

Schumm S. A., 1954: Evolution of drainage systems and slopes in badlands at Perth Amboy, New Jersey, ONR Technical Report 8, Project No. 389-1042, New York, Columbia University. 
Vanwalleghem T., Poesen J., Vitse I., Bork H. R., Dotterweich M., Schmidtchen G., Deckers J., Lang A., Mauz B., 2007: Origin and evolution of closed depression in central Belgium, European loess belt, Earth Surface Processes and Landforms 32, 574-586.

Zgłobicki W., 2002: Dynamika współczesnych procesów denudacyjnych w pótnocno-zachodniej części Wyżyny Lubelskiej, Wyd. UMCS, Lublin, 159.

\section{STRESZCZENIE}

W pracy omówiono cechy morfometryczne oraz rozmieszczenie zagłębień bezodpływowych obszarów lessowych Płaskowyżu Nałęczowskiego, subregionu geomorfologicznego położonego w północno-zachodniej części Wyżyny Lubelskiej (Polska południowo-wschodnia). Obszar ten jest zbudowany z lessów, których miąższość wynosi od kilku do ponad $30 \mathrm{~m}$. Pokrywa lessowa spoczywa na miąższych seriach zróżnicowanych pod względem litogenetycznym osadów glacigenicznych zlodowacenia odry. Dokonano inwentaryzacji zagłębień bezodpływowych na podstawie map topograficznych w skali 1: 10 000, a następnie w programie ArcGIS 9x przeprowadzono analizy ilościowe, w zakresie podstawowych charakterystyk morfometrycznych zagłębień takich jak: obwód, powierzchnia, głębokość, maksymalna długość oraz zwartość (kształt) zagłębień. Przeprowadzono analizy przestrzenne w celu określenia prawidłowości w zakresie rozmieszczenia zagłębień bezodpływowych na Płaskowyżu Nałęczowskim w oparciu o następujące charakterystyki ilościowe: gęstość, regiony koncentracji, rozmieszczenie na tle elementów rzeźby oraz przedziałów wysokościowych (wysokość n.p.m).

Wykonane badania wskazały na wzajemne podobieństwo zagłębień pod względem powierzchni, maksymalnej długości, kształtu (zwartości) i głębokości. Udokumentowano różnice dotyczące rozmieszczenia zagłębień bezodpływowych pomiędzy wschodnią i zachodnią częścią Płaskowyżu Nałęczowskiego, związane z odmiennymi cechami ukształtowania powierzchni tych obszarów. Wyróżniono zwarte obszary o dużej gęstości zagłębień, określane jako regiony wymokowe (gęstość powyżej 10 obiektów/ $\mathrm{km}^{2}$, maksymalnie 40 obiektów na $\mathrm{km}^{2}$ ), charakteryzujące się indywidualnymi cechami w zakresie morfometrii oraz rozmieszczenia zagłębień bezodpływowych.

Słowa kluczowe: zagłębienia bezodpływowe (wymoki), lessy, Płaskowyż Nałęczowski, Wyżyna Lubelska 